tig för att ge kunskap om den barnlitterära historien. För att kunna förstå såväl nutiden som nutidens litteratur behöver vi en bas att stå på och en kanon är ett sätt att skapa den.

Kanondebatten handlar som bekant inte bara om vilka böcker vi ger barnen utan även vad vi väljer att forska om. Trots att det finns en relativt stark barnlitterär forskningstradition i Sverige finns det fortfarande många mer eller mindre outforskade områden. Under de senaste tjugo åren har det utförts mycket forskning om litteratur skriven efter 1945, även om det kommer mer forskning om exempelvis det barnlitterära 1800-talet. Maria Nikolajeva påpekade att Sverige därvidlag skiljer sig från många andra länder. I exempelvis USA finns mycket forskning om äldre barnlitteratur, medan nyare texter fått mindre uppmärksamhet. Hon menade också att kanondebatten är olika i olika länder. I USA har man i hög grad gått ifrån kanonbegreppet, medan kanondiskussionen varit livlig i delar av Norden.

Svenska barnboksinstitutets konferens lockade deltagare från de flesta lärosäten i Sverige, men även från flera av de nordiska länderna. Det finns naturligtvis skillnader vad gäller forskningsinriktningar och möjligheter att ägna sig åt barn- och ungdomslitteraturforskning. I Sverige har barn- och ungdomslitteraturforskningen tveklöst en stark institutionell ställning idag. Två betydelsefulla och forskningsfrämjande etableringar är Center før børnelitteratur vid Pedagogiska Universitetet i Köpenhamn och det nu avslutade projektet"Children's Literature Pure and Applied" vid Åbo Akademi. Men den danska forskningen befinner sig till exempel, som Anna Karlskov Skyggebjerg påpekade, i en annan fas. Medan barnlitteraturforskare i Sverige och Norge börjat återupptäcka det pedagogiska perspektivet befinner sig Danmark i en avpedagogisering. Den danska barn- och ungdomslitteraturforskningen har alltså, med Boel Westins ord, ännu inte institutionaliseras. Men att det finns ett stort intresse för forskning runt barn- och ungdomslitteratur runt om i Norden utgjorde den breda uppslutningen och livliga diskussionen på konferensen ett bevis på.

Maria Andersson Elina Druker

\title{
Barntidningar - fanns dom? eller - här finns mycket att göra!
}

Vad har månne Göte Klingberg, Ingrid Sjöstrand, Elin Wägner, Jules Verne, William Faulkner och ett oräkneligt antal andra kulturpersonligheter och författare gemensamt? Jo, de debuterade i barntidningar. Hur många som, i likhet med August Strindberg, Ivar Lo-Johansson och makarna Bo och Margareta Strömstedt, i späda år stolta prenumererat på en egen tidning kan inte rekonstrueras. Närmast omöjligt är det också att överblicka alla etablerade barnboksförfattares och konstnärers alster som gömmer sig $\mathrm{i}$ tidskrifter. Att detta medium är värt vårt intresse är med andra ord uppenbart.

Det är alltså inte bara så som jag tidigare konstaterat att barnböcker finns, trots att många i det längsta undviker att identifiera dem såsom anpassade för just barn. Ett stort antal barntidningar fanns och har funnits i Sverige liksom - vågar man påstå - i alla 
skriftliga kulturer. Ändå är de föga uppmärksammade av eftervärlden.

Tidskrifter för barn och unga är som barnböcker en produkt av den förståndiga upplysningsepoken - ett skede som många extrema trosyttringar i samtiden kan få en att önska sig tillbaka. Då formade som bekant idéer om de yngres egenart en vilja att blanda "nytta med nöje" i inlärningsprocessen, samtidigt som tillvaron blev mer "modern" med allt fler nya upptäckter och uppfinningar som det var tacksamt att meddela läsarna i bok- och tidskriftsform. Hos en framväxande borgarklass uppstod behov av att kvalificera familjens unga för de positioner och privilegier som inte längre ärvdes utan berodde på individens egen kompetens. Något påminner ju detta om nutiden, då få föräldrar - trots hotande fetma, benurkalkning och pedofili - vill förbjuda sina barn att använda datorn.

Den första svenska tidning som vände sig till en ung läsekrets hette "Wecko-Blad Til Barns Nytta och Nöje" och utkom sporadiskt i Stockholm mellan 1766 och 1774. Även internationellt är detta ett av de tidigaste exemplen och den fick fram till sekelskiftet 1900 ett hundratal efterföljare. Men förhållandet är som sagt ganska okänt även i våra barnlitterära kretsar där man på sin höjd brukar kunna dra sig "Kamratposten" och "Lyckoslanten" till minnes. Redan detta faktum motiverar ju forskarinsatser - men det finns många andra orsaker att ta sig an barntidningarna.

Här ryms sålunda inte bara ett överrikt barnlitterärt stoff av både bilder och texter. Åtskilliga klassiska barn- och ungdomsböcker har först publicerats i tidskriftsform. Det gäller, för att bara ta ett exempel, R LStevensons odödliga Treasure Island, som relativt obemärkt löpte i Young Folks 1881-82. Men andra innehållskategorier som redak- tions- och läsarbrev, lärorika faktainslag och hobbyavdelningar vittnar ännu tydligare än samtida barnböcker om synen på läsarna och samhällets förhärskande ideal. I sin ambition att på ett begränsat utrymme ge läsarna inte bara fiktion och underhållning, utan även kunskap, moral och allmänt levnadsvett, avslöjar sig vuxensamhället utan förklädnad i eftervärldens ögon på ett sätt som då inte kunde förutses. Alltså må man, precis som när det gäller barnböckerna, undvika anakronistiska perspektiv när ideologin analyseras.

En speciell fascination erbjuder avnämarnas egna bidrag i den vitt spridda söndagsskolepressen eller tidningar riktade till folkskoleelever. Där växlas brev både mellan läsare och redaktion och mellan läsarna själva. Korrespondenserna ger livfulla vittnesbörd om äldre tiders barn- och ungdomstillvaro och återljuder av späda röster som för länge sedan tystnat och som inte bevarats i nästan några andra sammanhang.

Slutligen är detta ett medium vars historia - uppkomst, blomstring, nedgång och "fall" - av allt att döma snart kan överblickas. Få allmänkulturella barntidningar startas eller ens överlever idag. Desto fler internet-exempel uppträder som bekant, men dem får andra ta sig an. Låt mig i stället redogöra för mina forskningsplaner på barntidningsfältet och förutsättningarna för den som idag vill verka där.

\section{Målsättning}

- Att upprätta en bibliografi över svenska barn- och ungdomstidningar, i första hand för perioden 1766-1900, senare möjligen fram till 1950. Arbetet inriktas på regelbundet utkommande tidskrifter för yngre läsare, vare sig de givits ut av kommersiella förlag (ganska få) eller olika idé- och intresseorganisationer (före- 
trädande t ex religion, politik, nykterhet, scouting, djurskydd). Utanför hamnar tecknade serietidningar, tillfällestidningar, lokala skoltidningar och publikationer med huvudsakligt innehåll producerat av barn och unga. (Sistnämnda kategori är sällsynt före 1950.)

- Att skriva en monografi om de svenska barn- och ungdomstidningarnas historia, där sannolikt även resultatet av det bibliografiska arbetet redovisas. Frågeställningar som jag tidigare aktualiserat är genrer, namngivning (förutom "barnavänner" och "kamrater" uppträder åtskilliga blommor och fåglar!), genretypiska karaktäristika och innehållskategorier samt naturligtvis litterära och konstnärliga inslag. Därtill en omständighet som även intresserat andra forskare på senare år: relationen mellan tidning och läsare. Även ägareförhållanden, redaktörspersonligheter och utgivningsmönster (inklusive ev. följdskrifter) kommer att diskuteras.

- Att sammanställa en antologi med egna uppdaterade, tidigare publicerade och kanske även nyskrivna, studier i ämnet.

När vår länge planerade svenska barnlitteraturhistoria påbörjas, kan det bli aktuellt att där bidra med avsnitt om barntidningarnas utformning och roll i det barnlitterära fältet.

\section{Den svenska barnpressforskningens verktyg}

För avhandlingsarbetet disponerade jag bord A1 på universitetsbiblioteket Carolina $\mathrm{i}$ Uppsala och arbetade utan restriktioner i bibliotekets magasin. Det var tider! Men jag besökte även andra forskningsbibliotek och europeiska specialsamlingar. Nu blir i stäl- let KB och hemmet arbetsplatser. Men självklart kommer också Svenska barnboksinstitutets samlingar av både primär- och sekundärmaterial att utnyttjas.

Oumbärligt svenskt pressforskningsverktyg för perioden före 1900 är Bernhard Lundstedts Sveriges periodiska litteratur. Bibliografi 1-3 (1895-1902; faksimilutgåva 1969). Denne märklige man förtecknade hela den svenska periodiska utgivningen, inklusive barntidningarna, fram till sekelskiftet 1900 . (Under 1880-talet gjorde han också ett försök att bibliografera den finlandssvenska utgivningen.)

På senare år har uppföljningsprojektet "Nya Lundstedt" bedrivits i KB:s regi. Först tog man sig an det ofantliga berget av dagstidningar (jag kan bara pusta vid tanken på den samlade arbetsinsatsen!). Av större betydelse i mitt sammanhang är dock fortsättningen "Nya Lundstedt - tidskrifter" / "NLT" som drivs med externa medel sedan 2002 och är beräknat att avslutas 2006. Syftet är att bibliografera svenska tidskrifter 1900-1967. (För länkar se KB:s hemsida www.kb.se.)

Hittills har barntidningarna, enligt uppgifter från projektledaren Marika Holmblad, fått stå tillbaka, men nu är samtliga KB:s barntidningar utgivna mellan 1900 och 1955 med beteckningen "Undervisning. Barnböcker. Tidskrifter" inlagda. Snart tillkommer även de som rubricerats "Undervisning. Barnböcker. Samling". De blir då sökbara i LIBRIS. En komplikation är att endast förlagsutgivna barntidningar inom "populärpressen" (som jag uppfattar det den kommersiellt utgivna delen, inklusive serietidningar) beskrivs med angivelse av redaktörer och ansvariga utgivare - uppgifter som jag naturligtvis vill ha med i min bibliografi. Tidskrifter med anknytning till organisation, frikyrka eller dylikt bibliograferas på 
vad som definieras som nationalbibliografisk nivå, vilket innebär att uppgifter om redaktörer och ansvariga utgivare utelämnas. Här måste alltså den intresserade själv ta fram tidningsläggen.

$\mathrm{Nu}$ har jag ju sedan gammalt en viss vana, men nog hade det varit skönt att slippa den processen när någon annan haft hela materialet på en vagn. Och risken är som jag minns det att man blir sittande och bläddrar och häpnar över allt det material som här göms. Fast: det är verkligen inte förbjudet att ha roligt när man forskar!

STURE benämndes en svensk tidskriftsutredning under Bibliotekstjänsts outtröttlige Jan-Eric Malmquist som började rapporteras 1990 (Tidskriftiana. Rapport frän Statens kulturråd 1990:2). Den syftade till utvidgad indexering av svenska tidskrifter men var också incitament för Svensk presshistoria i fyra delar och ett registerband som $i$ imponerande fart utkom 2000-2003. Det är ett utomordentligt rikt och vackert arbete, framställt på ett av Sveriges äldsta tryckerier, Ekbladhs i Västervik, som tyvärr nyligen lagts ner. Där behandlar ett antal välrenommerade pressforskare såväl dagstidningar som tidskrifter i Sverige och deras allmänna förutsättningar, men materialet om barntidningar är närmast försumbart. Det jag planerar skulle alltså bli en välbehövlig komplettering.

Jan-Eric Malmquist var också redaktör för den av Kulturrådet 1988-2000 utgivna tidskriften Press på biblioteket som rymde mängder av historiska genomgångar och presentationer av svenska tidskrifter, därav två av mina egna större översikter.

Därtill finns sedan 1998 skriftserien "SYLWAN", namngiven efter pionjären Otto Sylwan (Svenska pressens historia till statshoüloningen 1772, 1896). Utgivare är det produktiva NORDICOM, forskningscentrum för medie- och kommunikationsfrågor vid Göteborgs universitet. Detta utgör självklart en viktig resurs i sammanhanget och har för övrigt samarbetat med SBI genom konferensen "Att mäta barns läsning" 2002. Av seriens hittills 14 utgivna titlar behandlar dock ingen barntidningar.

Presshistorisk årsbok ges sedan 1984 ut av Pressarkivets vänner. Där ingår hittills två större studier: 1988 Bertil Heddelins om Eva Wigströms Hvitsippan och 1991 min egen om barntidningarnas historia och viktigaste karaktäristika. Därtill kom i år en genomgång av Birgitta Lilliehööks arkiv ("Inte bara Spara och Slösa") av Ellinor Melander.

Av de svenska barnboksbibliografierna tar Göte Klingberg i sin första översikt 15911839 upp barntidningar, medan han i trebandsverket som går fram till 1889 (utgivet tillsammans med Ingar Bratt) utelämnar dem under hänvisning till att en bibliografi över barntidningar" under projekttiden hade påbörjats på annat håll". Det är alltså det avbrutna arbetet jag nu fortsätter. Inte heller Ingar Bratt inmänger i sin översikt täckande åren 1890-1899 barntidningar, däremot tacknämligt nog jultidningar och -kalendrar.

\section{Studier i barntidningar och barntidningsutgivning}

Sökning i SBI:s databas ELSA ger i augusti 2005 ca 170 träffar på sökordet "barntidningar", varav en dryg tredjedel fristående titlar, inklusive 3-betygs- och påbyggnadsuppsatser. Företeelsen har hittills avsatt åtskilliga internationella studier både i bokform och i tidskriftsartiklar (mest engelska, tyska och amerikanska men även nordiska) som i stor utsträckning finns i SBI:s referensbibliotek.

I Sverige har undersökningarna hittills varit ganska tunnsådda. 1962 utkom på ini- 
tiativ av en av våra stora pressgestalter, mångåriga KP-redaktören Margareta Toss, en charmerande skrift av historieprofessorn Sven Ulric Palme: Nåra anteckningar ur de svenska barntidningarnas historia. Sedan har tre monografier ägnats svenska barntidningar: Brita Tornells bok om Onkel Adams klassiska Linnea (1982), hennes lic. avhandling om Emily Nonnens Talltrasten (1989) och min egen avhandling Läsning för folkets barn. Folkskolans Barntidning och dess förlag 1892-1914 (1983). Jag har också sedan 1973 iSverige och utomlands publicerat ett tjugotal uppsatser och artiklar om svensk och internationell barnpress.

Några tidiga svenska publikationer har behandlats i gedigna trebetygsuppsatser. Folkskolans Barntidning och Kamratposten beskrevs 1974 av Jane Börjeson (Göteborg), Wecko-blad til barns nytta och nöje av Franz Luttenberger i Uppsala 1975 och de socialistiska Barntidningen och Den unge kamraten av Elias Fries, också i Uppsala 1974. Därtill finns akademiska elevuppsatser om jultidningar och -kalendrar samt ännu fler om Folkskolans Barntidnings efterföljare från 1950 Kamratposten. De sistnämnda behandlas ur olika aspekter av Anne-Li Lindgren i hennes avhandling från 1999 "Att ha barn med är en god sak": barn, medier och medborgarskap under 1930-talet och i en kommande avhandling av Catharina Hällström (som 2004 publicerade uppsatsen "En obruten historia. Folkskolans Barntidnings/Kamratpostens bakgrund, start och utveckling fram till idag"). Helena Magnussons snart färdiga avhandling om svenska tecknade barnserier kommer också att öka vår kunskap. På sena- re år har flera svenska barntidningar presenterats i den oumbärliga Opsis Kalopsis - vilket man gärna vill se som tecken på ett växande intresse för området.

En given resurs för mitt eget planerade arbete utgör allt redan insamlat material som, genom min kloke professors gränsdragningar, bara delvis kunde redovisas i avhandlingen. Där ingår förutom hekatomber av (mer eller mindre läsliga!) kopior även förteckningar av viktigt innehåll i svenska, nordiska, tyska och engelska barntidningar och kalendrar samt mängder av klipp och annat material som samlats in mellan de administrativa varven på SBI. Till detta kommer otryckta föredragsmanus och delvis kommenterade bibliografiska översikter från 1776 och framåt, byggande på Carolinas och KB:s bestånd omkring 1980.

Den här redovisade forskningsplanen är som alla inser minst sagt vidlyftig för en halvtidstjänst tillträdd ganska nära pensionen. Och visst borde detta arbete delas av flera. (Om någon, utöver det fåtal som redan är med på skutan, därav entusiasmeras att gripa sig an en forskningsuppgift på fältet kan ingen vara gladare än jag.) Men all forskning i stora materier kräver en viss, om än tyglad, galenskap. Jag börjar alltså med friskt mod och hoppas orka upp ur tidningshögarna när det blir dags att ställa sig i kö vid servicehemmets port. En del mindre förryckta individer lär ju numera vidta den åtgärden i 25årsåldern. Men de är förmodligen inte pressforskare.

Sonja Svensson 